\title{
Possibilities of Replacement of Two Side Metal Molds for the Production of Two Facing Side Composite by One Side Mold
}

Lukas Manas $^{1}$, Sona Rusnakova ${ }^{1}$, Milan Zaludek ${ }^{1}$, Ladislav Fojtl ${ }^{1}$, Vladimir Rusnak ${ }^{2}$

${ }^{1}$ Department of Production Engineering, Faculty of Technology, Tomas Bata University in Zlín. Vavrečkova 275,76001 Zlín.Czech Republic.E-mail: lmanas@ft.utb.cz,rusnakova@ft.utb.cz, zaludek@ft.utb.cz

${ }^{2}$ Faculty of Metallurgy and Materials Engineering, VŠB-Technical University of Ostrava, 17. listopadu 15, 70833 Ostrava-Poruba, Czech Republic. E-mail: vladimir.rusnak@form-composites.com

Presented research paper deals with possibilities of replacement of conventional mold materials by new, unconventional. Traditionally, laminate, wood or gypsum molds (in the case of small production series) are used for the production of composite parts. Furthermore, milled aluminum molds are conventionally used only for mass production. Due to this, thin metal sheet was prepared as an unconventional production mold for manufacturing of motorbike facing part. Vacuum bagging using prepared one side mold was chosen as the most appropriate technology. Normally, two facing sides are not commonly manufactured using this technology. Because of this, possibilities to create two facing sides at areas that are not in contact with mold itself were investigated. Presented results can help manufacturing companies with their production and considerably decrease manufacturing costs due to not necessity to use two side molds.

Keywords: Carbon fibers, Prepreg material, Metal sheet mold, Facing part, Vacuum bagging, Vacuum technology

\section{Acknowledgement}

This work was supported by the internal grant of TBU in Zlin No. IGA/FT/2014/003 funded from the resources of specific university research.

\section{References}

[1] CAMPBELL, F. (2010). Structural Composite Materials, Ohio, ASM International, 612 s., ISBN 978-161-5031405

[2] EHRENSTEIN, G. W. (2009). Polymerní kompozitní materiály. V ČR 1. vyd. Praha: Scientia, 351 s. ISBN 978 80-86960-29-6

[3] D. AGARWAL, BHAGWAN, LAWRENCE J. BROUTMAN, SODOMKA, L., BAREŠ, R., JAVORNICKÝ, J., ZEMÁNKOVÁ, J. (1987). Vláknové kompozity. 1. vydání. Praha: Nakladatelství technické literatury.

[4] Prepregs. Technical brochure, Gurit. [online]. (C) 2015 [cit. 2015-10-03]. Dostupný z: http://www.gurit.com/files/documents/prepreg-brochurev3pdf.pdf

[5] Technology. Prepreg technology, Hexcel. [online]. (C) 2015 [cit. 2015-10-05]. Dostupný z: http://www.hexcel.com:82/pdf/Technology\%20Manuals/Prepreg_Technology/index.html\#?page=26

[6] RUSNAKOVA, S., FOJTL, L., ZALUDEK, M., RUSNAK, V. (2014) Design of material composition and technology verification for composite front end cabs. Manufacturing Technology, Vol. 14, Issue 4, pp. 607-611, ISSN 1213-24

[7] RUSNAKOVA. S., ZALUDEK, M., BAKOSOVA, D. (2012). Processing engineering of large composites structures using low-pressure vacuum infusion. Manufacturing technology. Vol 12, No. 13, pp. 83-86, ISSN 1213-2489. 